\title{
Paleoenvironment of Carboniferous Shales in Wuwei Basin
}

\author{
Hui-yu HAN \\ School of Energy Resources, CUGB \\ China University of Geosciences, Beijing \\ Beijing, China \\ e-mail: 2425065222@qq.com \\ Yuan-yuan PENG \\ School of Energy Resources, CUGB \\ China University of Geosciences, Beijing \\ Beijing, China \\ e-mail: $854946290 @ q q . c o m$
}

\author{
Zhi-hong $\mathrm{KANG}^{*}$ \\ School of Energy Resources, CUGB \\ China University of Geosciences, Beijing \\ Beijing, China \\ e-mail: $250586274 @ q q . c o m$ \\ Lei ZHOU \\ School of Energy Resources, CUGB \\ China University of Geosciences, Beijing \\ Beijing, China \\ e-mail: $755302856 @ q q . c o m$
}

\begin{abstract}
Shales are enriched with diverse suites of trace elements that reflect their depositional environment. The purpose of this paper is to restitute the paleoenvironment of Carboniferous shales in Wuwei basin. In this study, we used and analyzed comprehensively trace elements $(\mathrm{B}, \mathrm{Sr}, \mathrm{Ba}, \mathrm{Ga}, \mathrm{V}$, $\mathrm{Ni}, \mathrm{Co}, \mathrm{U}, \mathrm{Th})$ data of shales. We resulted that shales for Carboniferous from the southern margin of the Wuwei basin were deposited in the hot and salty marine-continental transition environment.
\end{abstract}

\section{Keywords-shales;paleoenvironment; trace elements}

\section{INTRODUCTION}

The sedimentary environment not only affects the primary sedimentary structures and fossils in the sediments, but also affects the original geochemical enrichment and distribution of the sediments. With the development of geochemistry and the improvement of experimental instruments and the characteristics of trace elements in sediments that can well record the information of depositional evolution and reflect the paleoenvironmental, it is not only a supplement to the traditional sedimentary environment research methods, but also an important mean to quantitatively analyze the sedimentary environment by analyzing the elements migration, aggregation and distribution of sediments in the sedimentary-diagenetic process.

\section{SAMPLES AND TESTING}

Hongshuipu section is located to Gaojiadun Village in the northwest of Jingtai County, Gansu Province. According to the distribution characteristics of Carboniferous strata in the Hongshuiopu section of Wuwei basin, 20 samples of fresh and uncontaminated were collected from different parts of Carboniferous strata and the numbers of samples from bottom to top were HSP01-HSP20.

Measurements of trace elements(B, Sr, Ba, Ga, V, Ni, Co, U, Th) were analyzed by ELEMENT XR(Plasma mass spectrometer) and were carried out with an element inductively coupled plasma mass spectrometry (GB / T 14506.30-2010). Samples were analyzed by Analtical Laboratory of Beijing Research Institute of Uranium Geology. Test results were shown in Table 1:

\section{METHODS}

The contents of trace elements in sediments are closely related to the salinity, redox conditions, climate and water depth of sediment'sdepositional environment.In order to restore the sedimentary environment accurately, this paper analyzed the sedimentary environment of Carboniferous shales in Wuwei Basin from three aspects.

The contents of $\mathrm{B}$ and the ratios of $\mathrm{Sr} / \mathrm{Ba}, \mathrm{B} / \mathrm{Ga}$ and other geochemical indicators can be used to distinguish which is the sedimentary environment of Carboniferous shales between marine deposition or continental deposition, and understand the seawater salinity during the Carboniferous.The ratio of $\mathrm{Sr} / \mathrm{Ba}$ was used to analyze paleoclimate of sediments.Redox conditions were analyzed by using redox sensitive element indices, such as $\mathrm{wV} / \mathrm{w}(\mathrm{V}+\mathrm{Ni}), \delta \mathrm{U}, \mathrm{wV} / \mathrm{wCr}$ and $\mathrm{wNi} / \mathrm{wCo}$.

\section{DATA ANALYSIS AND INTERPRETATION}

\section{A. Paleosalinity}

\section{1) $B$}

Couch[1] studies suggest that the content of $\mathrm{B}$ in seawater is positively related to salinity in seawater.In general, the mass fraction of boron in marine environment is $80 \times 10^{-6} \sim 125 \times 10^{-6}$, and the mass fraction of boron in freshwater environment is less than $60 \times 10^{-6}$. The average mass fraction of boron in the samples from Hongshuipu section of Chouniugou Formation and Yanghugou Formation is $55 \times 10^{-6} \sim 154 \times 10^{-6}$, with an average of $95 \times 10^{-6}$. So, the Hongshuipu section of the Wuwei basin was the marine depositional environment during the Carboniferous.

In addition, the trend of sea level change can be analyzed by the change of Bcontent in sediments. Therefore, the content of $\mathrm{B}$ can be used to study the stratigraphic 
sequence of the basin.Affected by the river fresh water, the water-salinity of low system tract is decreased and the B contentofsediments in lower system tract is low.So, the B content of sediments in the highstand system tract (HST)is higher than that in the lowstand system tract (LST).The analysis of B content shows that there was generally a regression from Chouniugou Formation to Yanghugou Formation and were three complete secondary cyclic.

2) $B / G a$

The ratio of $\mathrm{B} / \mathrm{Ga}$ is an important index to infer thepaleosalinity of sediments.Generally, if the ratios of $\mathrm{B} / \mathrm{Ga}$ is greater than 4.2 , the depositional environment is the marine facies; if it is less than 3.3,the depositional environment is the continental facies; if it is between 4.2 and 3.3,the depositional environment is the transitional facies[2].The $\mathrm{wB} / \mathrm{wGa}$ of samples from Hongshuipu section of Chouniugou Formation and Yanghugou Formation ranged from 2.37 to 6.41 , with an average value of 3.55 , so it belonged to marine-land transitional faciesin general. The ratios of $\mathrm{B} / \mathrm{Ga}$ decreases in general, but there are two peaks in the lower part for Yanghugou Formation(Fig 1). It showed that there was a process of regression from Early Carboniferous to Late Carboniferous in general but was also a small-scale transgression movement during Late Carboniferous.

\section{B. Paleoclimate}

$\mathrm{Sr}$ and $\mathrm{Ba}$ are the same kind of elements and have a relatively similar chemical properties, but the solubility of the $\mathrm{Ba}$ compound is lower than that of the $\mathrm{Sr}$ element[3].When the salinity of the lake is reduced and the climate is humid and evaporation is slow, the Ba-carbonate tends to precipitate, resulting in a smaller $\mathrm{Sr} / \mathrm{Ba}$ value.So, the $\mathrm{Sr} / \mathrm{Ba}$ ratio is an important indicator for restoring paleoclimate.It is generally considered that $\mathrm{wSr} / \mathrm{wBa}<0.6$ represents a low salinity of the water and a relatively humid climate deposition, $\mathrm{wSr} / \mathrm{wBa}$ between 0.6 to 1.2 represents a high salinity and dry climate, $\mathrm{wSr} / \mathrm{wBa}>1.2$ represents a high salinity and dry environment.

The average $\mathrm{wSr} / \mathrm{wBa}$ of the samples from Hongshuipu section of Chouniugou Formation and Yanghugou Formation ranged from 0.43 to 2.32 , with an average value of 1.04, and most values were between 0.6 and 1.2.This showed that the period from Chouniugou Formation and Yanghugou Formation was semi-humid - semi-arid climate.

\section{Redox}

\section{1) $\mathrm{V} /(\mathrm{V}+\mathrm{Ni})$}

The ratios of $\mathrm{V} /(\mathrm{V}+\mathrm{Ni})$ can indicate redox conditions of the water. High ratios $(>0.84)$ reflect that sediments deposited under anoxic conditions that the water layer is obvious;medium ratios $(0.6 \sim 0.84)$ reflect that sediments deposited under anoxic conditions that the water layer is not obvious.Low ratios $(0.46-0.60)$ reflect that sediments deposited under anoxic conditions. The ratios of $\mathrm{V} /(\mathrm{V}+\mathrm{Ni})$ in the samples from Hongshuipu section of the Chouniugou Formation and Yanghugou Formation ranged from 0.69 to 0.96 , with an average value of 0.87 , indicating that Carboniferous Shales in Wuwei Basin deposited under anoxic conditions that the water layer is obvious.

2) $\delta U$

Wignall[4] proposed $\delta \mathrm{U}$ index: $\delta \mathrm{U}=\mathrm{U} /[1 / 2(\mathrm{U}+\mathrm{Th} / 3)]$, $\delta \mathrm{U}>1$ indicates anoxic conditions, $\delta \mathrm{U}<1$ reflects that the sedimentary environment is the normal redox conditions.The mean $\delta U$ of the Hongshuipu section is 1.12 , and most of the values are greater than 1.This indicated that redox conditions of Hongshuipu section is anoxic conditions during the Carboniferous.

\section{3) $\mathrm{Ni} / \mathrm{Co}$}

Element ratios of $\mathrm{Ni} / \mathrm{Co}$ have been used to infer water conditions during black shale deposition. HigherNi/Co ratios relate to increasingly deficient oxygen levelsduring deposition, due to the relative easeat which $\mathrm{Ni}$ is sequestered by organic matter in reducingsediments. Co concentrations are thought to be a function ofdetrital content, and not influenced by redox conditions .Generally, $\mathrm{Ni} / \mathrm{Co}<5$ is for the oxidizing environment, $\mathrm{Ni} / \mathrm{Co}$ value of 5 to 7 is for the weak oxidation environment, $\mathrm{Ni} / \mathrm{Co}>7$ is for the reduction environment. The $\mathrm{Ni} / \mathrm{Co}$ values of the samples from Hongshuipu section are averagely 7.46, most of which are greater than 7 , suggesting lower oxygen regimes duringdeposition of Chouniugou Formation and Yanghugou Formation

\section{CONCLUSIONS}

A. Based on the data, it was found that the shales of Carboniferous in the southern margin of the Wuwei basin was mainly deposited in the hot and salty marine-continental transition facies and the reduction environment that was conducive to the enrichment of organic.

B. Through the paleosalinity analysis, it was considered that there was generally a regression and were three complete secondary cyclic during Carboniferous in the southern margin of the Wuwei basin, but there was also a small-scale transgression movement during Late Carboniferous.

\section{REFERENCES}

[1] Couch E L. CALCULATION OF PALEOSALINITIES FROM BORON AND CLAY MINERAL DATA[J]. American Association of Petroleum Geologists Bulletin, 1971, 55(10):1829-1837.

[2] Deng H W, Qian K. Sedimentary Geochemistry and Environment Analysis[M]. Lanzhou:Gansu Science and Technology Press, 1993.

[3] Wang A H. Discriminant effects of sedimentary environment by the $\mathrm{Sr} / \mathrm{Ba}$ ratio of different existing forms $[\mathrm{J}]$. Acta Sedimentologica Sinica, 1996, 14(4): 168-173.

[4] Xiong Xiaohui, Xiao Jiafei. Geochemical indicators of sedimentary environments[J]. Earth and Environment, 2011, 39(3):405-414 
TABLE I. TEST RESULTS OF TRACE ELEMENTS

\begin{tabular}{|c|c|c|c|c|c|c|c|c|c|c|}
\hline \multicolumn{11}{|l|}{ Trace Element } \\
\hline Sample name & $\begin{array}{l}\text { B } \\
\mu \mathrm{g} / \mathrm{g}\end{array}$ & $\begin{array}{l}\mathrm{Sr} \\
\mu \mathrm{g} / \mathrm{g}\end{array}$ & $\begin{array}{l}\text { Ba } \\
\mu \mathrm{g} / \mathrm{g}\end{array}$ & $\begin{array}{l}\text { Ga } \\
\mu \mathrm{g} / \mathrm{g}\end{array}$ & $\begin{array}{l}\mathrm{V} \\
\mu \mathrm{g} / \mathrm{g}\end{array}$ & $\begin{array}{l}\mathrm{Cr} \\
\mu \mathrm{g} / \mathrm{g}\end{array}$ & $\begin{array}{l}\mathrm{Ni} \\
\mu \mathrm{g} / \mathrm{g}\end{array}$ & $\begin{array}{l}\text { Co } \\
\mu \mathrm{g} / \mathrm{g}\end{array}$ & $\begin{array}{l}\mathrm{U} \\
\mu \mathrm{g} / \mathrm{g}\end{array}$ & $\begin{array}{l}\text { Th } \\
\mu \mathrm{g} / \mathrm{g}\end{array}$ \\
\hline \multicolumn{11}{|c|}{ Yanghugou Formation } \\
\hline HSP20 & 86.8 & 216 & 415 & 36.3 & 150 & 188 & 18.1 & 2.24 & 9.02 & 30.6 \\
\hline HSP19 & 86.8 & 456 & 457 & 35.4 & 126 & 122 & 21.2 & 2.55 & 7.07 & 22.8 \\
\hline HSP18 & 73.5 & 308 & 352 & 31 & 213 & 166 & 12.4 & 1.68 & 12.6 & 25.2 \\
\hline HSP17 & 82.7 & 187 & 429 & 33.2 & 143 & 132 & 13.5 & 1.97 & 7.51 & 25.5 \\
\hline HSP16 & 55 & 102 & 237 & 21.3 & 93.3 & 80.1 & 16.5 & 1.8 & 11.5 & 21.1 \\
\hline HSP15 & 144 & 202 & 391 & 33.6 & 461 & 655 & 20.3 & 1.63 & 15.6 & 23.3 \\
\hline HSP14 & 92.2 & 355 & 435 & 32.9 & 192 & 245 & 13.7 & 1.37 & 13.1 & 24.5 \\
\hline HSP13 & 89.2 & 394 & 396 & 26.2 & 152 & 155 & 12.8 & 1.54 & 8.95 & 24.5 \\
\hline HSP12 & 61.6 & 46.3 & 98.5 & 9.6 & 44 & 95.5 & 5 & 0.698 & 6.03 & 9.41 \\
\hline HSP11 & 86.7 & 192 & 260 & 28.5 & 133 & 168 & 17 & 1.79 & 9.86 & 18.8 \\
\hline HSP10 & 85.3 & 217 & 357 & 27.9 & 175 & 154 & 16 & 2.07 & 8.22 & 24.7 \\
\hline HSP09 & 56.9 & 210 & 199 & 21 & 102 & 146 & 13.8 & 1.47 & 7.52 & 14 \\
\hline HSP08 & 65.2 & 929 & 162 & 18.6 & 123 & 105 & 8.25 & 0.955 & 8.82 & 17.9 \\
\hline \multicolumn{11}{|c|}{ Chouniugou Formation } \\
\hline HSP07 & 127 & 456 & 240 & 27.7 & 135 & 121 & 13.1 & 1.6 & 11.9 & 24.2 \\
\hline HSP06 & 142 & 173 & 283 & 29.4 & 169 & 147 & 55.7 & 13.3 & 8.42 & 21.9 \\
\hline HSP05 & 120 & 195 & 296 & 30.2 & 185 & 143 & 82.2 & 24.6 & 6.59 & 23.8 \\
\hline HSP04 & 154 & 465 & 380 & 34.4 & 238 & 167 & 76 & 18.4 & 16.4 & 27.6 \\
\hline HSP03 & 134 & 196 & 322 & 32.1 & 191 & 145 & 47.3 & 13.5 & 8.15 & 25.8 \\
\hline HSP02 & 74.6 & 221 & 337 & 28.3 & 93.4 & 120 & 21.1 & 3.02 & 10.5 & 28.1 \\
\hline HSP01 & 89.8 & 208 & 196 & 18.5 & 112 & 117 & 8.06 & 1.35 & 8.21 & 16.5 \\
\hline
\end{tabular}

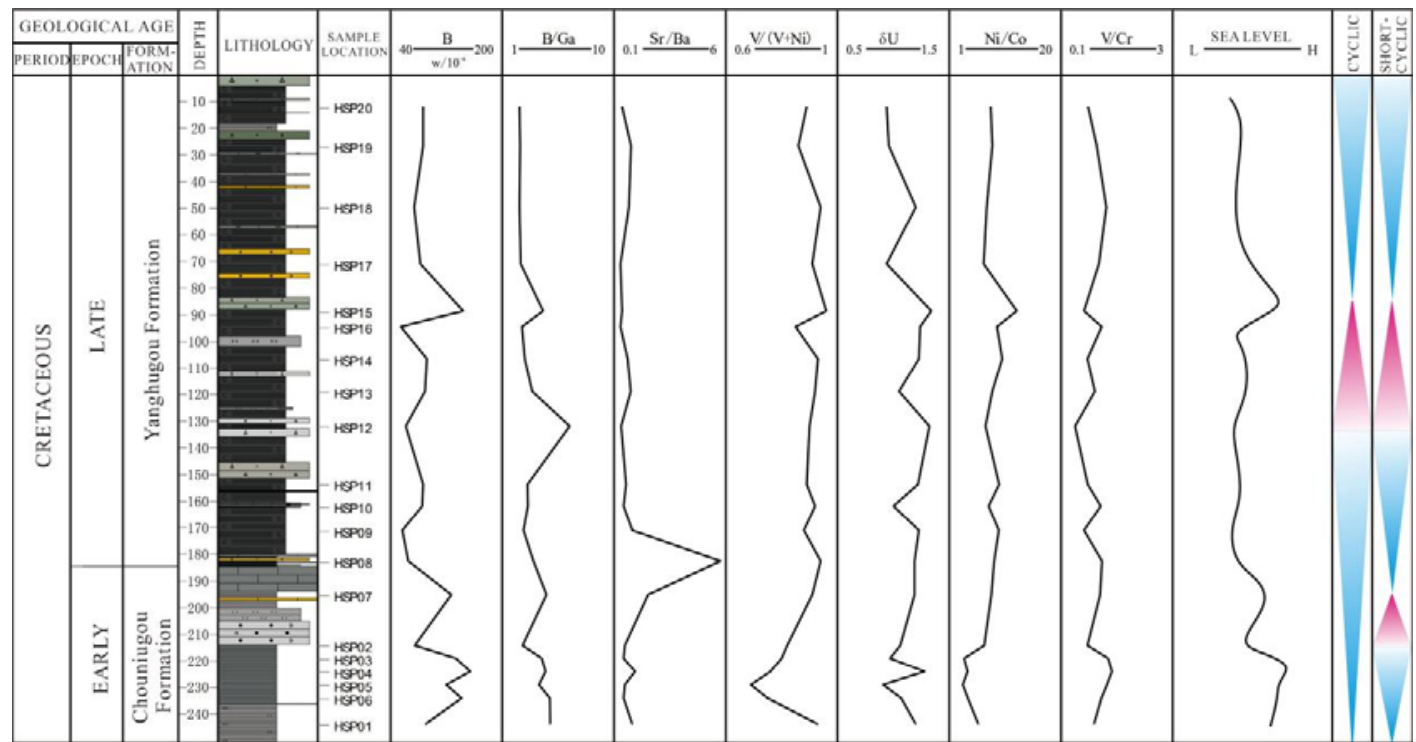

Figure 1. The relationship between sea level change, element, element ratios for the Chouniugou Formation and Yanghugou Formation, Hongshuipu Section 